\begin{tabular}{l} 
Sharif University of Technology \\
Scientia Iranica \\
SCIENTIA \\
IRANICA \\
Transtions A: Civil Engineering \\
\hline
\end{tabular}

\title{
The effect of gusset plate in moment-rotation behavior of double-web angle connection in braced frames
}

\author{
M. Mofid* and A.R. Tabkhi Wayghan \\ Department of Civil Engineering, Sharif University of Technology, Tehran, Iran.
}

Received 5 October 2015; received in revised form 6 May 2016; accepted 29 August 2016

\author{
KEYWORDS \\ Double-web angle \\ connection; \\ Moment rotation \\ curve; \\ Braced frame; \\ Semi-hinge \\ connection; \\ Gusset plate.
}

\begin{abstract}
Double-web angle connection is one of the most rudimentary connections in simple structural systems such as braced frame system. It is essentially presumed in conventional designs that double-web angle connection behaves as a hinge connection. However, in braced frames, due to existence of braces in some bays, in specified locations where gusset plates of brace are placed with beam-to-column connection in one joint, this assumption may not be accurate. This is due to the restraining of the beam from rotation by gusset plates that are placed either on the top and bottom of the beam or only on one side. In such cases, the simple beam-to-column connection may be transformed into a semi-hinge or fixed connection. In this paper, double-web angle connection is investigated in the mentioned locations by using the FEM method along with calculating moment rotation behavior of connection and, subsequently, type and rigidity of the connection. Furthermore, an analytical model is proposed to predict the characteristics of the doubleweb angle connection in the view of the relevant case.
\end{abstract}

(C) 2017 Sharif University of Technology. All rights reserved.

\section{Introduction}

Connections and their behavior are contributing factors in designing a steel structure. Generally, before the analysis and the design of a structure, the behavior and type of the connection should be specified.

Beam-to-column connections are classified into three types: fixed (rigid), semi-rigid (semi-hinge), and flexible (simple). In the past, using flexible and semi-rigid connections in seismic zones was rarely recommended by design codes. In 1991, Nader and Astaneh showed that flexible and semi-rigid connections behaved well in most of laboratory tests and

\footnotetext{
*. Corresponding author. Tel.: +98 21 66022727; Fax: +982166014828

E-mail addresses: mofid@sharif.edu (M. Mofid);

a.tabkhi@gmail.com (A.R. Tabkhi Wayghan)
}

these structures had considerable potential for resisting earthquake loading [1].

The braced frames, in which gusset plates are placed either on the top and bottom of the beam or only on one side of the beam, may prevent the beam from rotation in beam-to-column connections. Basically, they transform the connection from hinge connection to semi-hinge or even fixed connection. This event should be considered in the analysis and design of a structure, since it impresses both analysis and design.

In this paper, double-web angle connection is examined regarding places and the effect of existence of gusset plate on the moment-rotation behavior of the beam-to-column connection being studied. A parametric analysis is done using FEM method in order to investigate the influence of effective parameters on the behavior of the connection. Furthermore, an analytical model is proposed to predict the initial stiffness and the ultimate moment of connection, and its results are compared with FEM as well as experimental results. 


\section{Previous research}

There are numerous research studies performed on double-web angle connection and gusset plates as well as their behavior. However, the research conducted on the effect of gusset plates on double-web angle connection behavior is very limited. The first research on the behavior of double-web angle connection was completed in 1917 by Wilson and Moore [2] and it was continued in 1936 by Rathbun [3]. They used riveted connections in their research. Although the behavior of riveted connections is similar to that of nonhigh-strength bolts, their results were not beneficial for new designs. McMullin and Astaneh performed 7 fullscale tests on double-web angle connection in 1988 . Some of their conclusions were as the following: 1) Fracturing of the weld at the top of the connection is by far the most common mode of failure; 2) Double-web angle connections are superior to shear tabs, because they have low rotational stiffness; therefore, they transfer less moment into the column; and 3) Overall performance of double-web angle connections is quite acceptable; they resist high shears, allow rotation of the beam end, and, moreover, pass negligible moment to the column [4]. Abolmaali et al. performed some tests to investigate the cyclic behavior of double-web angle connections in 2003. They concluded that in the case of angles bolted to both beam and column, connections could pass 2 to 16 percent of the plastic moment of beam to column. Also, they showed that if angles were connected to beam web through weld and to column flange through bolt, the connection would pass 5 to 45 percent of the plastic moment of beam to column [5]. The research on gusset plates has been started in about one hundred years ago. However, one of the first documented experiments on gusset plates subjected to cyclic loading was performed by AstanehAsl et al. [6-11]. Their research consisted of 17 fullscale double-angle bracing members with end gusset plates subjected to cyclic loading. Their research indicated that the cyclic behavior of gusset plates in braced frames strongly depended on the direction of buckling of the bracing member. In the case that the bracing member buckles in the plane of the braced frame, three plastic hinges form in the member, one at mid-length and two others at each end of the member just outside the gusset plate. However, in the case that the bracing member buckles out of the plane of the braced frame, one plastic hinge still forms at midlength of the member, but two other hinges form inside the gusset plate. Formation of plastic hinges in the gusset plate shows that the gusset plate should be designed such that it can resist the relatively large rotation demands of the plastic hinge [6-11]. Lehman et al. in 2008 performed a study on improvement of seismic performance of gusset plate connections.
Their study focused on the gusset plate clearance; the size and type of weld used to connect the gusset plate to the framing elements; and the impact of the gusset plate stiffness, thickness, and geometry. They proposed an elliptical clearance requirement instead of the $2 \mathrm{t}$ linear clearance distance proposed earlier to improve both the constructability and performance of the connections [12].

The first research pertaining to the effect of gusset plates on double-web angle connection behavior was completed in 1988 by Gross and Cheok [13]. They tested braced frames under monotonic loading. However, their research mostly focused on the performance of braced frame; it was ultimately concluded that gusset plates increased rigidity and stiffness of the beam-to-column connection [13]. The most evident research regarding the topic in question has been done in 2012 by Stoakes. He completed eight experimental tests in full scale in order to probe flexural stiffness, strength, and ductility, which are the main criteria of AISC code in classification of steel beam-to-column connections [14].

\section{Modeling}

The type of connection considered in this research pertains to a double-web angle connection where one or two gusset plates are attached to beam and column through welds or a combination of bolts and welds, on top and bottom of the beam. The overall view of the created models in FEM software are shown in Figure 1(a) and (b).

\subsection{Materials}

Materials such as steel parts, bolts, and welds are modeled using the nonlinear behavior of each one accordingly. For steel parts, they comprise the beam, column, angles, and gusset plates along with St-37 steel used according to DIN standard. For this type of steel, a tri-linear stress-strain curve is considered. As regards the type of welds, E60 electrode with bi-linear stress-

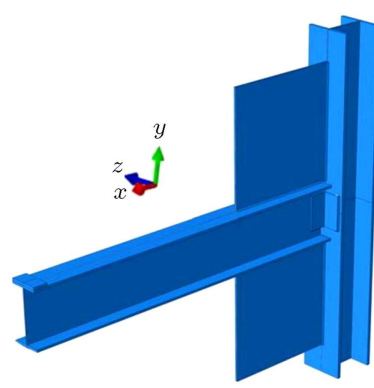

(a)

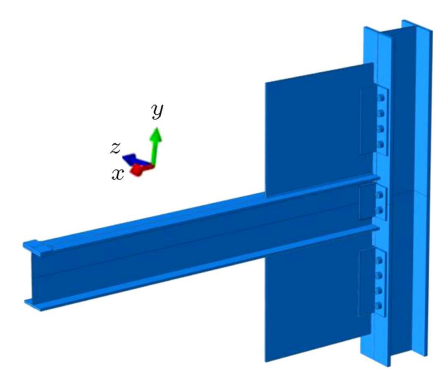

(b)
Figure 1. Overall view of the created models in FEM software: (a) Fully welded connections, and (b) bolted and welded connections. 
Table 1. Characteristics of used materials.

\begin{tabular}{cccccccc}
\hline Material & $\begin{array}{c}\boldsymbol{\sigma}_{\boldsymbol{y}} \\
(\text { yield } \\
\text { stress) }\end{array}$ & $\begin{array}{c}\boldsymbol{\sigma}_{u} \\
(\text { ultimate } \\
\text { stress) }\end{array}$ & $\begin{array}{c}\boldsymbol{\varepsilon}_{\boldsymbol{y}} \\
\text { (yield } \\
\text { strain) }\end{array}$ & $\begin{array}{c}\boldsymbol{\varepsilon}_{\boldsymbol{p}} \\
(\text { plastic } \\
\text { strain) }\end{array}$ & $\begin{array}{c}\boldsymbol{\varepsilon}_{\boldsymbol{u}} \\
\text { (ultimate } \\
\text { strain) }\end{array}$ & $\begin{array}{c}\text { (elasticity } \\
\text { modulus) }\end{array}$ & $\boldsymbol{v}$ \\
\hline Steel [15] & $240 \mathrm{MPa}$ & $370 \mathrm{MPa}$ & 0.001142 & 0.01257 & 0.1371 & $2.1 \times 10^{5} \mathrm{MPa}$ & 0.3 \\
Bolt [15] & $640 \mathrm{MPa}$ & $800 \mathrm{MPa}$ & 0.00305 & 0.00914 & 0.0244 & $2.1 \times 10^{5} \mathrm{MPa}$ & 0.3 \\
Weld [16] & $336 \mathrm{MPa}$ & $420 \mathrm{MPa}$ & 0.0016 & - & 0.22 & $2.1 \times 10^{5} \mathrm{MPa}$ & 0.3 \\
\hline
\end{tabular}

strain curve is considered. Additionally, as for bolts, high-strength bolts of type A325 (according to ASTM) or 8.8 (according to DIN) with tri-linear stress-strain curve are considered. The characteristics of the used materials are presented in Table 1.

\subsection{Parametric study}

In order to investigate the influence of effective parameters on moment-rotation behavior of double-web angle connection in the considered locations, a parametric study is performed. The considered parameters comprise beam section, thickness of gusset plate, dimensions of gusset plate, column section, the clip distance at the end of gusset plate, and the existence of one or two gusset plates on the edges of the beam. All of the parameters are introduced in nomenclature and in Figure 2(a) and (b).

In this paper, 53 models are provided to perform a parametric study. At the same time, 40 models out of 53 are related to fully welded connections, where no bolts are applied in them, and are named "M1" to "M40". Overall specifications of these models are shown in Figure 2(a). Furthermore, the characteristics of these models are described in Table 2. The "M1"
Table 2. Characteristics of models "M2" to "M20".

\begin{tabular}{ccc}
\hline Model & $\begin{array}{c}\text { Changed parameter } \\
\text { in comparison } \\
\text { with model "M1" }\end{array}$ & $\begin{array}{c}\text { Value of the } \\
\text { changed parameter in } \\
\text { the present model }\end{array}$ \\
\hline M2 & Beam & IPE220 \\
M3 & IPE200 \\
M4 & IPE270 \\
M5 & IPE300 \\
M6 & IPE400 \\
M7 & Gusset plate & $6 \mathrm{~mm}$ \\
M8 & thickness & $8 \mathrm{~mm}$ \\
M9 & & $12 \mathrm{~mm}$ \\
M10 & Gusset plate & $15 \mathrm{~mm}$ \\
M11 & dimensions & $400 \times 300 \mathrm{~mm}$ \\
M12 & & $600 \times 400 \mathrm{~mm}$ \\
M13 & Column & HEB160 \\
M14 & section & HEB240 \\
M15 & & HEB300 \\
M16 & Clip distance & $25 \mathrm{~mm}$ \\
M17 & at the end & $50 \mathrm{~mm}$ \\
M18 & of gusset plate & $100 \mathrm{~mm}$ \\
M19 & & $150 \mathrm{~mm}$ \\
M20 & &
\end{tabular}

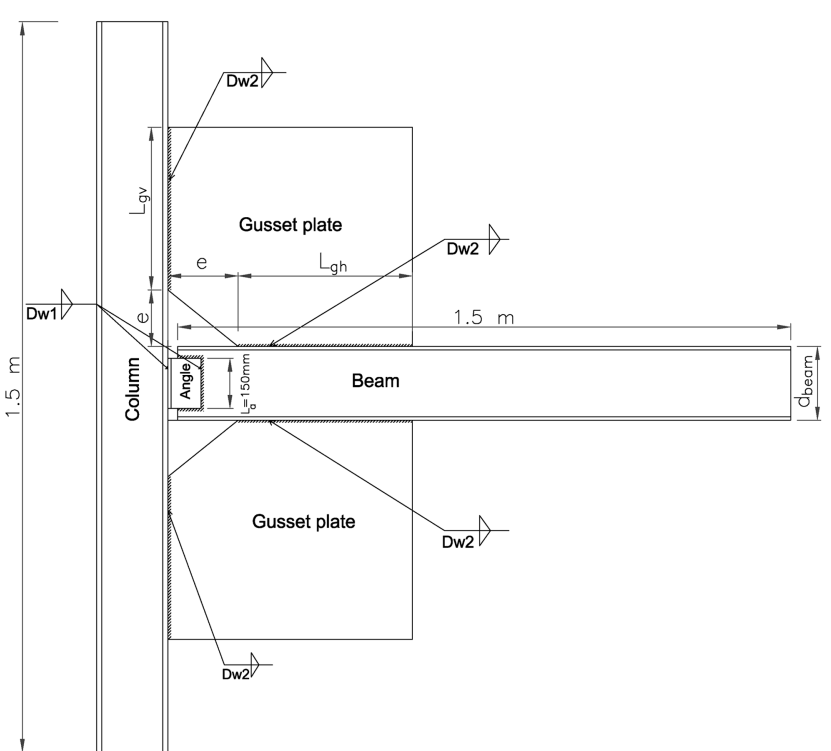

(a)

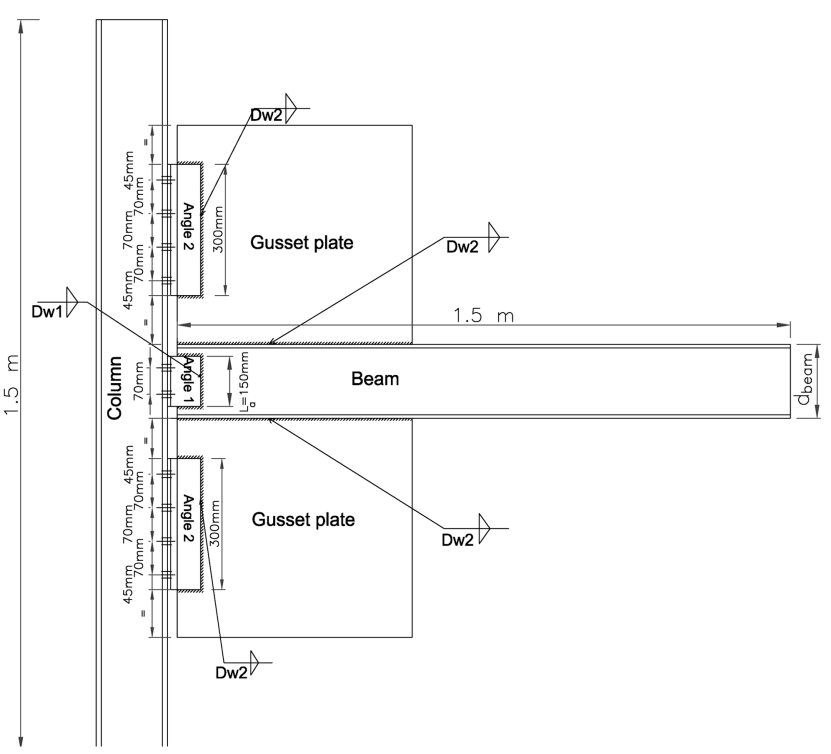

(b)

Figure 2. (a) Overall specifications of "M1" to "M40" models (fully welded connections). (b) Overall specifications of "MWB1" to "MWB13" models (bolted and welded connections). 
Table 3. Characteristics of models "MWB3" to "MWB7".

\begin{tabular}{lcc}
\hline Changed parameter & $\begin{array}{c}\text { Value of the } \\
\text { in comparison } \\
\text { with model } \\
\text { "MWB2" }\end{array}$ & $\begin{array}{c}\text { changed parameter in } \\
\text { the present model }\end{array}$ \\
\hline MWB3 & Beam & IPE200 \\
MWB4 & section & IPE300 \\
MWB5 & Gusset plate & $300 \times 300 \mathrm{~mm}$ \\
MWB6 & dimensions & $400 \times 400 \mathrm{~mm}$ \\
MWB7 & & $600 \times 600 \mathrm{~mm}$ \\
\hline
\end{tabular}

model is considered as the base model and other models are created based on this model in the view of changing a parameter. For "M1" model, "HEB200" is applied to section of column, "IPE240" to beam section, gusset plates with $500 \times 500 \times 10 \mathrm{~mm}$ dimensions that are welded to beam, and column with an $8 \mathrm{~mm}$ fillet weld. Moreover, " $L 80 \times 80 \times 8$ " as web angles with a length of $150 \mathrm{~mm}$ is welded to beam and column with a $6 \mathrm{~mm}$ fillet weld. It is distinctively distinguished that models "M21" to "M40" are the same models as "M1" to "M20," respectively, with the only difference of one gusset plate, which exists on the bottom of the beam, being removed (one gusset plate on top of the beam still remains). Also, in all 53 models, the gap distance between the beam and the column is considered to be $20 \mathrm{~mm}$.

Also, 13 out of the 53 models are related to the connections where the bolts and welds applied to them are synchronous, and are named "MWB1" to "MWB13". Overall specifications of these models (including position and spacing of bolts, etc.) are shown in Figure 2(b) and characteristics of these models are furthermore elaborated in Table 3. The "MWB1" model is precisely same as the "test1" model, which was considered by Stoakes [17] in his experimental tests. The "MWB2" model is considered as the base model for this case and other models ("MWB3" to "MWB13") are formed based on this model, but by changing a parameter. For the "MWB2" model, the same sections as those in model "M1" are applied with the only difference being that angles and gusset plates are connected to the column through bolts in two columns. Regarding the angles, two rows of bolts and four rows for gusset plates with $20 \mathrm{~mm}$ of diameter for each bolt are used. As mentioned earlier, it is evident that models "MWB8" to "MWB13" are same as the models "MWB2" to "MWB7", respectively. However, the only difference is that one gusset plate, which exists on the bottom of the beam, is removed (one gusset plate on top of the beam still remains).

\subsection{Loading}

Two loading conditions are considered in this research, namely, monotonic and cyclic. All models are analyzed using monotonic loading, except for three models, which are subjected to cyclic loading using SAC loading protocol [17]. Monotonic loading is applied to a rigid plate at the end of the beam in the form of pressure in order to avoid stress concentration, while cyclic loading is applied in the form of displacement loading at the end of the beam.

\subsection{Meshing and analysis options}

In this research, two continuum solid element types are used. The first one is a three-dimensional element with eight nodes and one integration point; the other one is a three-dimensional ten-node tetrahedron element with four integration points. In the base model, there are a total number of 18,017 elements, 32,639 nodes, 63,464 Gauss integration points, and 134,685 degrees of freedom. For important and susceptible areas such as web angles and welds, a fine mesh is used; while for other parts such as beam, gusset plate, and column, a coarse mesh in comparison with other parts is used. "Full Newton" technique is chosen as solution technique and "Direct method" is chosen as equation solver. Both material and geometrical nonlinearities are considered in the model. Large strain tensors are used in FEM models.

\subsection{Shear locking and spurious zero energy mode}

Shear locking phenomenon is an undesirable numerical effect of the inclusion of transverse shear strain effects in finite element schemes [18]. As Nascimbene mentioned, "Shear locking appears in a numerical formulation which is not able to represent a state of zero shear in the thin limit, independent of the mesh size. As the thickness becomes extremely thin, the shear strain energy predicted by the finite element model can be magnified unreasonably." [18]. Also, shear locking appears in elements with large aspect ratios. In these elements, they tend to stiffen and lose accuracy as their aspect ratio increases. One of the solutions to alleviate numerical locking is reduced integration approach [18]. In this investigation, for tetrahedron elements, the average aspect ratio of elements is 2.87 and the worst aspect ratio is 8.80 , which makes these elements unlikely for shear locking.

The strain energy of an element is equal to $U=\frac{1}{2} \underline{d}^{T} \underline{k d}=\frac{1}{2} \int_{V^{e}} \underline{\varepsilon}^{T} \underline{D \varepsilon} d V$. If $U$ is equal to zero for a mode $d$, which is different from a rigid body mode, then $d$ is known as a spurious zero energy mode or hourglass mode. The mentioned mode is not desirable and this phenomenon does not appear in the full integration elements used in this research. Hourglassing could be a problem with first-order, reducedintegration elements. However, hour-glassing could be minimized by distributing point loads and boundary 
conditions over a number of adjacent nodes. In FEM models, which are used in this paper, in addition to using a fine mesh, loads are also applied in a distributed manner using a rigid plate as described in Section 3.3. Therefore, appearing spurious zero energy mode or hourglass mode is unlikely in the existing FEM model.

\section{Analytical model}

In this paper, an analytical model is proposed to predict the performance of deliberated connection with some equations. Analytical model is provided using component method. In this method, connection is divided into some components and it is presumed that each component behaves as a linear spring. Thereafter, all springs are connected to each other as series or parallel springs and initial stiffness of the overall connection is calculated. In addition, the ultimate moment, which can be carried by connection, is calculated in this paper using the formation of plastic hinges.

\subsection{Evaluation of the initial stiffness}

Components that may be effective in evaluating initial stiffness are web angles, gusset plate, and column. First, the center of rotation of connection should be specified. In the case that two gusset plates exist on top and bottom of the beam, according to FEM models, the center of rotation is in the range of $0.4 d_{\text {beam }}$ to $0.6 d_{\text {beam }}$ above the bottom of the lower flange of beam. Therefore, the center of rotation, in this case, is considered by the average value of $0.5 d_{\text {beam }}$ above the bottom of the lower flange of beam. In the case that only one gusset plate exists on top of beam, according to FEM models and the research of Stoakes [14], the center of rotation is above the top of the upper flange of beam. Through the analysis of all models, it is observed that the center of rotation position is a function of beam depth and gusset plate dimensions. Therefore, the distance of center of rotation from the top of gusset plate is evaluated as follows (lengths are in the unit of $\mathrm{mm}$ ):

$$
\begin{gathered}
\left(-0.00078 d_{\text {beam }}{ }^{2}+63.08 d_{\text {beam }}+0.00056\left(L_{g h} \times L_{g v}\right)\right. \\
\left.-45.81 \sqrt{L_{g h} \times L_{g v}}\right) .
\end{gathered}
$$

\subsubsection{Web angle stiffness}

The stiffness of a web angle is calculated by assuming that the angle acts as a cantilever beam and a concentrated load is applied to the end of the beam [14]. This is calculated in Eq. (1):

$$
k_{i}=\frac{P_{i}}{\Delta_{i}}=\frac{1}{\frac{L^{3}}{3 E I}+\frac{L}{G A_{s}}} .
$$

The length of cantilever beam, $L$, is considered as the width of leg of angle minus the back welded width (here, back welded width is considered equal to $2 \mathrm{~cm}$ ) for welded connections. Also, parameters $I$ and $A_{s}$ are calculated by assuming a rectangular section with a height equal to angle thickness and a width equal to $d y$, in which $d y$ is the differential element along the length of angle $L_{a}$. Finally, the stiffness of connection due to web angles is calculated in Eq. (2):

$$
\begin{aligned}
K_{\text {angles }} & =2 \int_{-\frac{L_{a}}{2}}^{\frac{L_{a}}{2}} k_{i} y^{2} \\
& =2 \int_{-\frac{L_{a}}{2}}^{\frac{L_{a}}{2}} \frac{1}{\frac{L^{3}}{3 E\left(d y \cdot \frac{t^{3}}{12}\right)}+\frac{L}{G\left(\frac{5}{6} d y \cdot t\right)}} y^{2} \\
& =\frac{5 G E t^{3} L_{a}^{3}}{120 G L^{3}+36 L E t^{2}} .
\end{aligned}
$$

The presence of multiplier 2 is due to the existence of two angles on the edges of web of the beam.

In the case where only one gusset plate is considered on top of the beam, the process guideline followed is exactly such as above, with exceptions only in the integral intervals. The $\left[\frac{L_{a}}{2}\right]$ should be changed to:

$$
\begin{aligned}
{\left[L_{g v}\right.} & -\left(-0.00078 d_{\text {beam }}^{2}+63.08 d_{\text {beam }}\right. \\
& \left.+0.00056\left(L_{g h} \times L_{g v}\right)-45.81 \sqrt{L_{g h} \times L_{g v}}\right) \\
& \left.+\frac{d_{\text {beam }}+L_{a}}{2}\right]
\end{aligned}
$$

and $\left[-\frac{L_{a}}{2}\right]$ should be changed to:

$$
\begin{aligned}
{\left[L_{g v}\right.} & -\left(-0.00078 d_{\text {beam }}{ }^{2}+63.08 d_{\text {beam }}\right. \\
& \left.+0.00056\left(L_{g h} \times L_{g v}\right)-45.81 \sqrt{L_{g h} \times L_{g v}}\right) \\
& \left.+\frac{d_{\text {beam }}-L_{a}}{2}\right] .
\end{aligned}
$$

\subsubsection{Gusset plate and column stiffness}

Stiffness of gusset plate and column stiffness are calculated through application of Silva et al. [19] recommendation. It is noted that the deformation of weld could be neglected; in other words, the stiffness of weld can be considered infinite. Therefore, gusset plate and column are considered where they perform together. The analytical model for gusset plate and column for a case that there are two gusset plates on top and bottom of the main beam is considered as a beam that is illustrated in Figure 3. Furthermore, the considered section of the beam along its length is nonprismatic. The bottom of beam length is the center of 

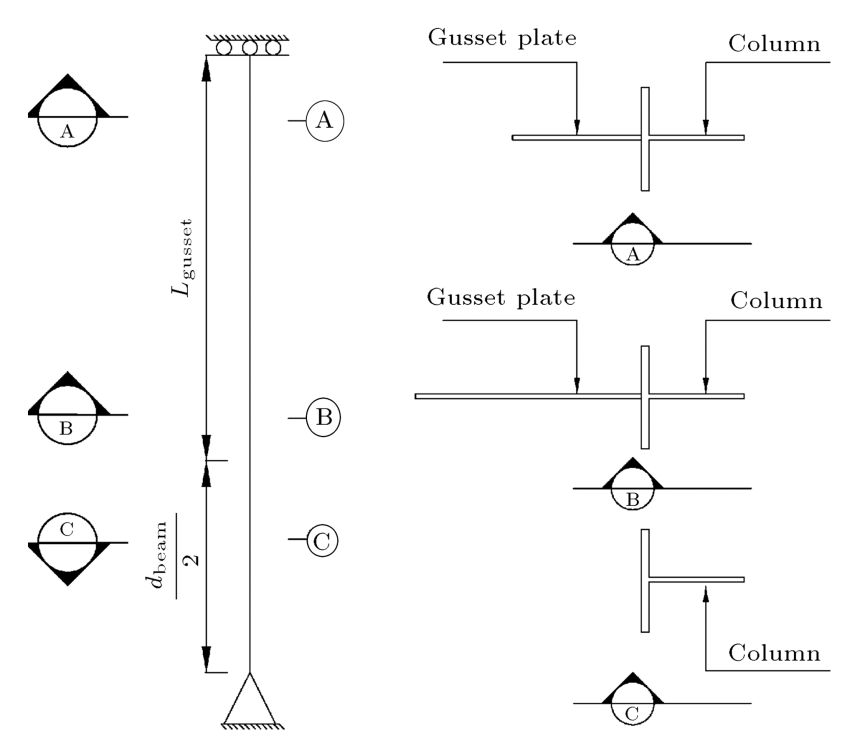

Figure 3. Analytical model for gusset plate and column stiffness in the case where two gusset plates exist.

rotation of connection as opposed to the top of beam length being the end of gusset plate. In addition, based on the slight participated role of a segment of gusset plate in connection behavior, this segment in particular is not considered in calculating stiffness. Therefore, the height of gusset plate at the topmost part of the contemplated beam is considered to be 35 percent of the real height. At the same time, the right flange segment of the column (the flange that is not connected to the gusset plate) does not contribute to connection behavior and it is not considered in calculating the stiffness.

Through the assumption of linear stress distribution along the considered beam length and applying a concentrated load to the center of gravity of stress distribution (in two thirds of the gusset plate length plus half of the main beam height), rotational stiffness of connection due to gusset plate and column can be calculated. Moreover, by analyzing this beam through operating a computer program based on the dimensions of connection, Eq. (3) is proposed for calculating the stiffness of connection due to gusset plate and column:

$$
K_{\text {gusset }+ \text { column }}=\frac{1}{\frac{5}{9} \frac{L}{E I_{\text {eff }}}+\frac{3}{2 L G A_{\text {eff }}}} .
$$

In Eq. (3), the parameters $L, I_{\text {eff }}$, and $A_{\text {eff }}$ are defined in Eqs. (4) to (8) (all units are in $\mathrm{mm}$ ):

$$
\begin{aligned}
& L=L_{g v}+\frac{d_{\text {beam }}}{2}+e, \\
& I_{\text {eff }}=I \cdot \frac{d_{\text {beam }}}{960} \cdot \sqrt{\frac{b_{f c}}{200}} \cdot \sqrt{\frac{h_{w c}}{185}}, \\
& A_{\text {eff }}=0.6\left(L_{g h} \cdot t_{g}+h_{w c} \cdot t_{w c}\right),
\end{aligned}
$$

$$
\begin{aligned}
I= & \frac{h_{w c}^{3} \cdot t_{w c}}{12}+\frac{L_{g h}^{3} \cdot t_{g}}{12}+b_{f c} \cdot t_{f c}\left(z-h_{w c}\right)^{2} \\
& +h_{w c} \cdot t_{w c}\left(z-\frac{h_{w c}}{2}\right)^{2} \\
& +L_{g h} \cdot t_{g}\left(\frac{L_{g h}}{2}+h_{w c}-z\right)^{2}, \\
z= & \quad \begin{array}{l}
0.5 \cdot h_{w c}^{2} \cdot t_{w c}+b_{f c} \cdot t_{f c} \cdot h_{w c}+L_{g h} \cdot t_{g} \cdot\left(h_{w c}+t_{f c}+\frac{L_{g h}}{2}\right) \\
h_{w c} \cdot t_{w c}+b_{f c} \cdot t_{f c}+L_{g h} \cdot t_{g}
\end{array}
\end{aligned}
$$

The stiffness of the connection for a case where there is only one gusset plate on top of the beam due to gusset plate and column is basically calculated using Eq. (9). Hence, the applied parameters in Eq. (9) are computed using Eq. (10) and Eqs. (5) to (8):

$$
\begin{aligned}
& K_{\text {gusset }+ \text { column }}=\frac{1}{\frac{L}{E I_{\text {eff }}}+\frac{1}{L G A_{\text {eff }}}}, \\
& L=L_{g v}+d_{\text {beam }}+2 e .
\end{aligned}
$$

\subsubsection{Total stiffness of connection}

The total stiffness of the connection is calculated by summing $K_{\text {gusset+column }}$ and $K_{\text {angles }}$ in a case where two gusset plates do exist in connection. On the other hand, for a case in which only one gusset plate exists in connection, the stiffness is calculated by summing up the related $K_{\text {gusset+column }}$ plus the related $K_{\text {angles }}$.

\subsection{Evaluation of the ultimate moment of connection and the moment-rotation curve derived from the analytical model}

In order to evaluate the ultimate moment that can be carried by the connection, various criteria can be considered. In the case that there are two gusset plates on top and bottom of the beam, four criteria are considered. The first criterion is shear yielding of the gusset plate section. According to code AISC36010, the capacity of shear yielding in an element of connection is derived by Eq. (11). In Eq. (11), the parameter $A_{g v}$ pertains to the gross shear area [20]. According to this criterion, the ultimate moment that can be carried by the connection is calculated by multiplying Eq. (11) by the arm of this force from the center of rotation, which is equal to half of beam depth:

$$
\begin{aligned}
& R_{n}=0.6 F_{y} A_{g v}, \\
& M_{u 1}=2 .\left(0.6 F_{y} L_{g h} . t_{g}\right) \frac{d_{\text {beam }}}{2}=0.6 F_{y} L_{g h} . t_{g} \cdot d_{\text {beam }} .
\end{aligned}
$$

The second criterion involves column web local yielding due to both compressive and tensile forces being 
exerted to column through gusset plate. According to AISC360-10, the capacity of column in this case is derived from Eq. (13) [20]. Additionally, the ultimate moment that can be supported by connection according to this criterion can be derived from Eq. (14). Eq. (14) is calculated by multiplying Eq. (13) by the force arm, presuming linear force distribution from the center of rotation:

$$
\begin{aligned}
& R_{n}=F_{y} t_{w} \cdot\left(5 k+l_{b}\right), \\
& M_{u 2}=\frac{4}{3} F_{y} t_{w c} \cdot\left(5 t_{f c}+L_{g v}\right) \cdot\left(\frac{d_{\text {beam }}}{2}+L_{g v}\right) .
\end{aligned}
$$

The third criterion is based on formation of plastic hinges. According to the generated models, locations of plastic hinges in connection are in the corner of gusset plate. A model is generated accordingly and is shown in Figure 4. The force $P_{i}$ is derived based on linear stress distribution as well as by equalizing internal work and external work during a unit virtual rotation. Furthermore, the calculation of $P_{i}$ is described through Eqs. (15) to (17). The plastic moment of the gusset plate section is derived from Eq. (18). Finally, the ultimate moment that can be supported by connection is due to this criterion being derived from Eq. (19). The calculated moment is reached essentially through gusset plate and shall be summed up with the moment that can be supported by angles, but the angle portion is negligible. Therefore, only the moments that can be supported by gusset plates are considered:

$$
\begin{aligned}
& W_{e}=P_{i}\left[\frac{2}{3}\left(\frac{d_{\text {beam }}}{2}+L_{g v}+e\right)-\frac{d_{\text {beam }}}{2}\right] \theta, \\
& W_{i}=M_{p}(\theta+2 \theta+\theta), \\
& W_{e}=W_{i} \rightarrow P_{i}=\frac{4 M_{p}}{\frac{2}{3} L_{g v}-\frac{1}{6} d_{\text {beam }}+\frac{2}{3} e}, \\
& M_{p}=Z F_{y}=\frac{t_{g}\left[\frac{\left(0.35 L_{g v}\right)^{2}+\left(0.35 L_{g h}\right)^{2}}{2}\right]}{4} F_{y},
\end{aligned}
$$

$$
\begin{aligned}
M_{u 3}= & 2 . P_{i}\left[\frac{2}{3}\left(\frac{d_{\text {beam }}}{2}+L_{v g}+e\right)\right] \\
& =\frac{\frac{2}{3} t_{g}\left[\left(0.35 L_{g v}\right)^{2}+\left(0.35 L_{g h}\right)^{2}\right]}{\frac{2}{3} L_{g v}-\frac{1}{6} d_{\text {beam }}+\frac{2}{3} e} \\
& \left(\frac{d_{\text {beam }}}{2}+L_{g v}+e\right) F_{y} .
\end{aligned}
$$

The fourth criterion is based on the plastic moment capacity of the beam. This moment is derived from Eq. (20):

$$
M_{u 4}=F_{y} Z_{b}
$$

Finally, the ultimate moment that can be supported by connection is the minimum value that is obtained from the described criteria.

\subsection{Calculating the moment-rotation curve using the initial stiffness and the ultimate moment of connection}

In order to calculate moment-rotation curve through application of initial stiffness and ultimate moment of connection, the studies by Mohammadi and Mofid [21], Lee and Moon [22], and Stelmack et al. [23] are used. Regarding moment-rotation curve, bilinear curve is applied.

The parameter $K_{i}$ is the initial stiffness of the connection and $K_{p}$ is the secant or plastic stiffness of the connection. There is no acceptable generic way to compute plastic stiffness through analytical method at the present time [21]. Generally, the plastic stiffness is defined as a ratio of initial stiffness through an empirical method. According to studies by Mohammadi and Mofid [21], Lee and Moon [22], and Stelmack et al. [23], the ratio of plastic stiffness to initial stiffness ranges from 0.02 to 0.20 . In addition, by surveying these studies, it is understood that if rigidity of a connection increases, the ratio of plastic stiffness to initial stiffness will also be increased. Therefore, for the considered

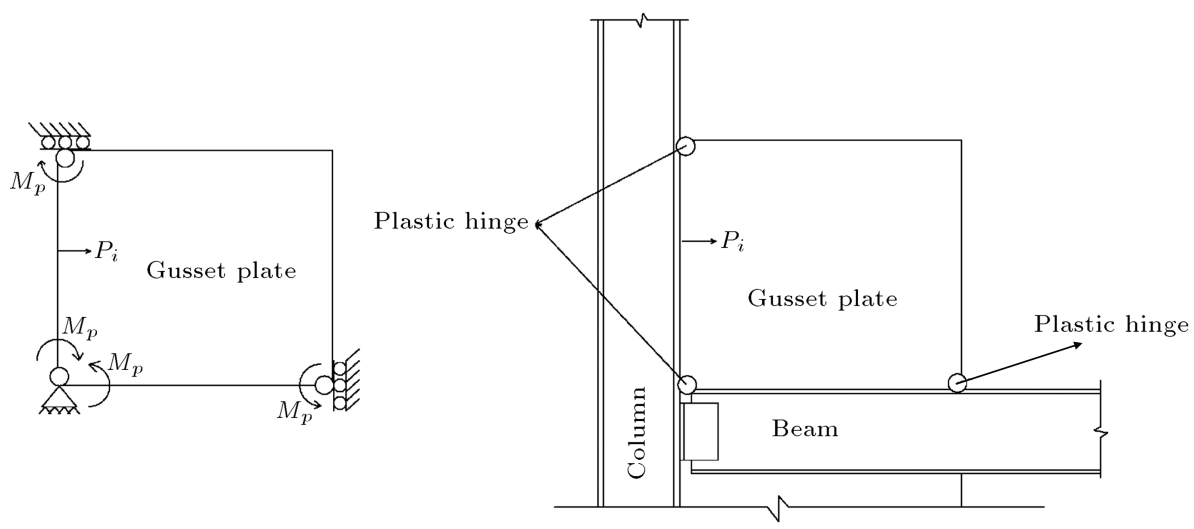

Figure 4. Plastic hinges location and analytical model for the case where two gusset plates exist in top and bottom of the beam. 
models, due to their high rigidity, the plastic ratio is taken equal to 0.05 to 0.15 times the initial stiffness. Moreover, the parameter $M_{0}$ is called the intercept moment, which is considered equal to 0.75 times the ultimate moment $M_{u}$ according to the recommendation of Mohammadi and Mofid [21].

\section{Results}

\subsection{Finite element model results with monotonic loading}

Ultimately, the results from all 53 models are presented in this section. These results are shown as classified by the changed parameters. Figure 5 is related to models "M1" to "M6" and the effect of beam section is examined in it. In Figures 6 to 9, the effect of gusset plate thickness, gusset plate dimensions, column section, and the clip distance at the end of gusset plate are explored, respectively. Figures 10 to 14 are also related to models "M21" to "M40".

From the preceding results that are illustrated in Figures 5 to 10, the following obtained consequences can be understood. First, by increasing the beam depth, initial stiffness, ultimate moment, and ultimate rotation of connection increase; however, the rigidity of connection will be decreased. Also, by increasing the gusset plate thickness or increasing column section size, initial stiffness and rigidity of connection will be increased and ultimate rotation will be decreased. On the other hand, there is no significant change in the ultimate moment of connection. Additionally, the other changed parameter is gusset plate dimensions.

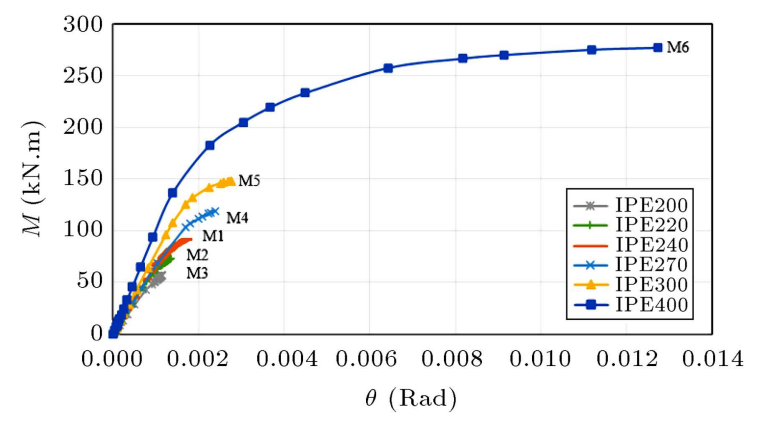

\begin{tabular}{cccc}
\hline Model Beam section & $\begin{array}{c}\text { Dimensionless } \\
\text { parameter } \\
\frac{K_{s} L}{E I}\end{array}$ & $\begin{array}{c}\text { Connection } \\
\text { classification }\end{array}$ \\
\hline M3 & IPE 200 & 69.99 & Rigid \\
M2 & IPE 220 & 56.40 & Rigid \\
M1 & IPE 240 & 41.87 & Rigid \\
M4 & IPE 270 & 27.27 & Rigid \\
M5 & IPE 300 & 22.53 & Rigid \\
M6 & IPE 400 & 10.13 & Semi-rigid \\
\hline
\end{tabular}

Figure 5. Effect of beam section (with two gusset plates).

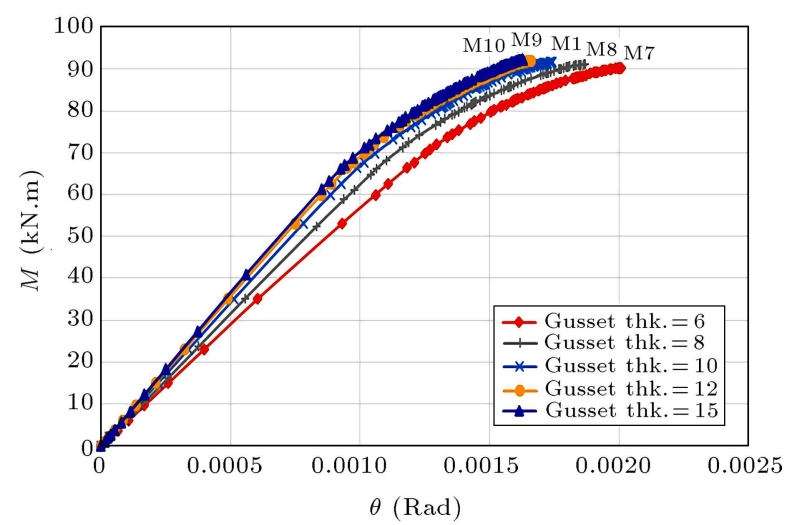

\begin{tabular}{cccc}
\hline Model & $\begin{array}{c}\text { Gusset plate } \\
\text { thickness } \\
(\mathbf{m m})\end{array}$ & $\begin{array}{c}\text { Dimensionless } \\
\text { parameter, } \\
\frac{K_{\boldsymbol{s}} \boldsymbol{L}}{E I}\end{array}$ & $\begin{array}{c}\text { Connection } \\
\text { classification }\end{array}$ \\
\hline M7 & 6.00 & 35.45 & Rigid \\
M8 & 8.00 & 38.02 & Rigid \\
M1 & 10.00 & 41.87 & Rigid \\
M9 & 12.00 & 43.46 & Rigid \\
M10 & 15.00 & 44.83 & Rigid \\
\hline
\end{tabular}

Figure 6. Effect of gusset plate thickness (with two gusset plates).

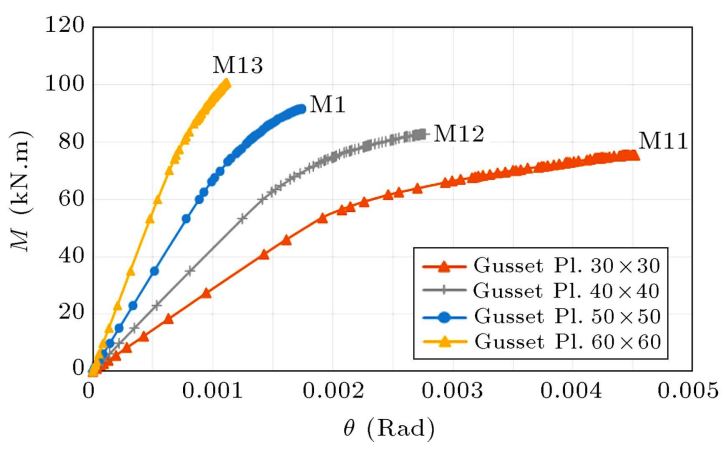

\begin{tabular}{cccc}
\hline Model & $\begin{array}{c}\text { Gusset plate } \\
\text { dimensions } \\
(\mathbf{c m})\end{array}$ & $\begin{array}{c}\text { Dimensionless } \\
\text { parameter, } \\
\frac{K_{\boldsymbol{S}} L}{E I}\end{array}$ & $\begin{array}{c}\text { Connection } \\
\text { classification }\end{array}$ \\
\hline M11 & $30 \times 30$ & 17.54 & Semi-rigid \\
M12 & $40 \times 40$ & 26.13 & Rigid \\
M1 & $50 \times 50$ & 41.87 & Rigid \\
M13 & $60 \times 60$ & 67.79 & Rigid \\
\hline
\end{tabular}

Figure 7. Effect of gusset plate dimensions (with two gusset plates). 


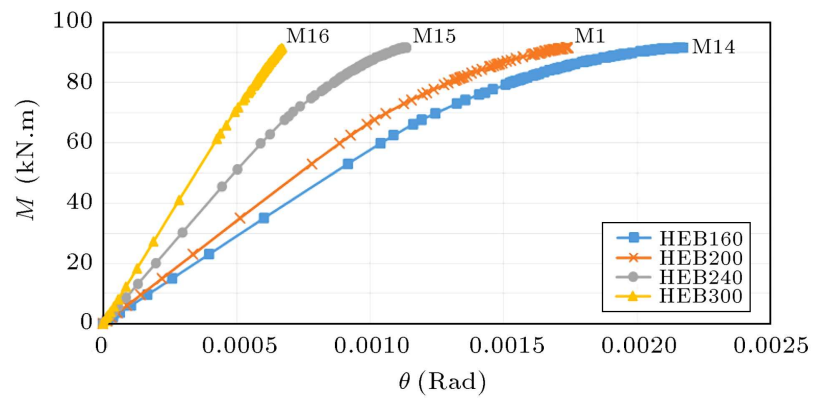

\begin{tabular}{cccc}
\hline Model & $\begin{array}{c}\text { Column } \\
\text { section }\end{array}$ & $\begin{array}{c}\text { Dimensionless } \\
\text { parameter, } \\
\frac{K_{s} L}{E I}\end{array}$ & $\begin{array}{c}\text { Connection } \\
\text { classification }\end{array}$ \\
\hline M14 & HBE160 & 35.66 & Rigid \\
M1 & HBE200 & 41.87 & Rigid \\
M15 & HBE240 & 62.58 & Rigid \\
M16 & HBE300 & 88.53 & Rigid \\
\hline
\end{tabular}

Figure 8. Effect of column section (with two gusset plates).

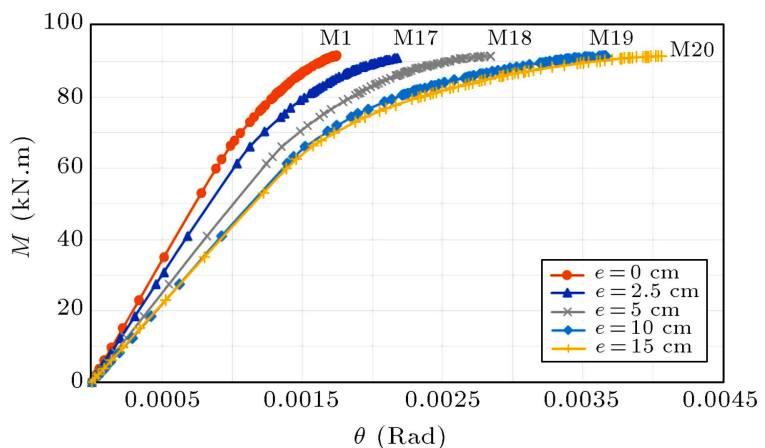

\begin{tabular}{cccc}
\hline Model & $\begin{array}{c}\text { Clip distance } \\
\text { at the end of } \\
\text { gusset plate, } \boldsymbol{e}(\mathbf{c m})\end{array}$ & $\begin{array}{c}\text { Dimensionless } \\
\text { parameter, } \\
\frac{K_{s} L}{E I}\end{array}$ & $\begin{array}{c}\text { Connection } \\
\text { classification }\end{array}$ \\
\hline M1 & 0 & 41.87 & Rigid \\
M17 & 2.5 & 36.74 & Rigid \\
M18 & 5 & 30.49 & Rigid \\
M19 & 10 & 26.53 & Rigid \\
M20 & 15 & 26.47 & Rigid \\
\hline
\end{tabular}

Figure 9. Effect of clip distance at the end of gusset plate (with two gusset plates).

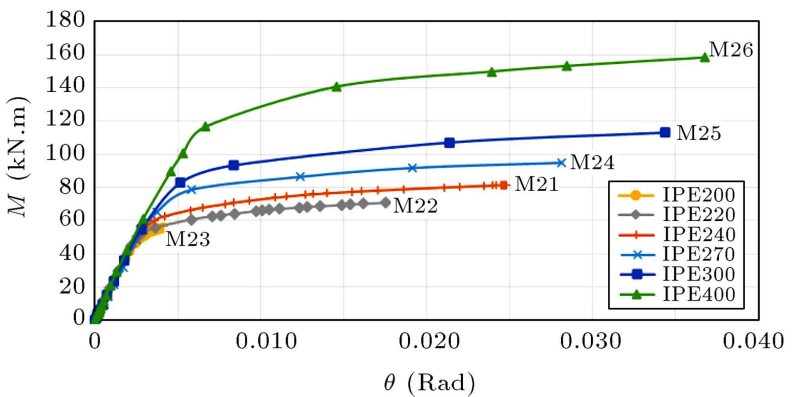

\begin{tabular}{llcc}
\hline Model & $\begin{array}{c}\text { Beam } \\
\text { section }\end{array}$ & $\begin{array}{c}\text { Dimensionless } \\
\text { parameter, } \\
\frac{K_{s} L}{E I}\end{array}$ & $\begin{array}{c}\text { Connection } \\
\text { classification }\end{array}$ \\
\hline M23 & IPE200 & 26.20 & Rigid \\
M22 & IPE220 & 18.49 & Semi-rigid \\
M21 & IPE240 & 12.27 & Semi-rigid \\
M24 & IPE270 & 7.70 & Semi-rigid \\
M25 & IPE300 & 5.59 & Semi-rigid \\
M26 & IPE400 & 2.17 & Semi-rigid \\
\hline
\end{tabular}

Figure 10. Effect of beam section (with one gusset plate).

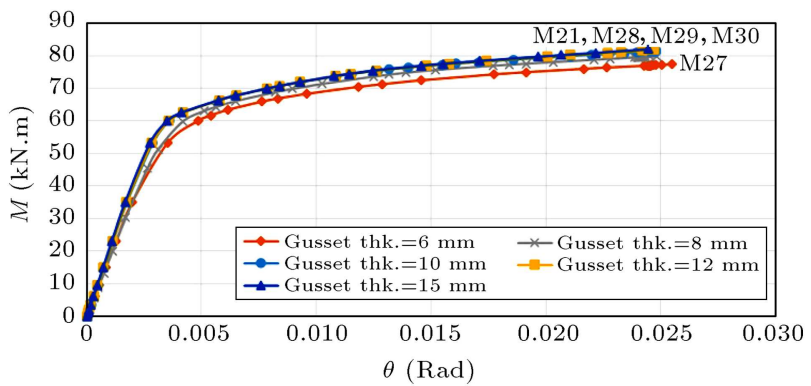

\begin{tabular}{lccc}
\hline Model & $\begin{array}{c}\text { Gusset plate } \\
\text { thickness } \\
(\mathbf{m m})\end{array}$ & $\begin{array}{c}\text { Dimensionless } \\
\text { parameter, } \\
\frac{K_{s} L}{E I}\end{array}$ & $\begin{array}{c}\text { Connection } \\
\text { classification }\end{array}$ \\
\hline M27 & 6 & 10.29 & Semi-rigid \\
M28 & 8 & 10.92 & Semi-rigid \\
M21 & 10 & 12.27 & Semi-rigid \\
M29 & 12 & 12.61 & Semi-rigid \\
M30 & 15 & 13 & Semi-rigid \\
\hline
\end{tabular}

Figure 11. Effect of gusset plate thickness (with one gusset plate).

By increasing gusset plate dimensions, the initial stiffness, ultimate moment, and rigidity of connection will be increased while ultimate rotation of connection will be decreased. The other parameter is the clip distance at the end of gusset plate whose increase will lead to decrease in initial stiffness and rigidity of connection. However, it results in increase in the ultimate rotation and makes no significant change in the ultimate moment of connection.

Comparing models "M21" to "M40" with models "M1" to "M20" evidently shows that the results presented above are still stable. However, by removing the bottom gusset plate from bottom of the beam, initial stiffness, ultimate moment, and rigidity of con- 


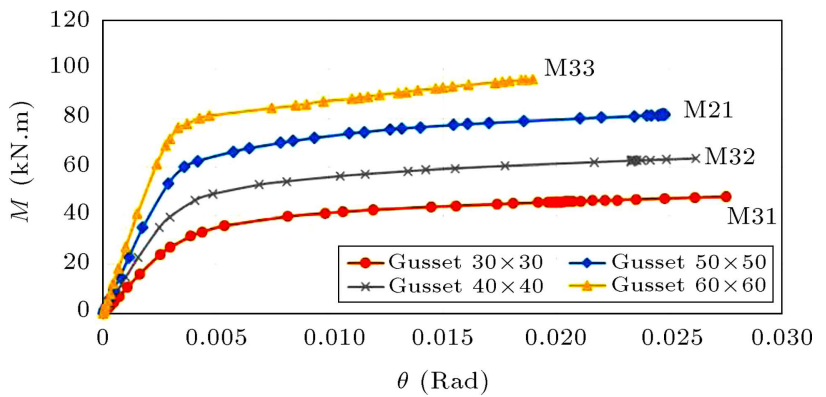

\begin{tabular}{cccc}
\hline Model & $\begin{array}{c}\text { Gusset plate } \\
\text { dimensions } \\
(\mathbf{c m})\end{array}$ & $\begin{array}{c}\text { Dimensionless } \\
\text { parameter, } \\
\frac{K_{s} L}{E I}\end{array}$ & $\begin{array}{c}\text { Connection } \\
\text { classification }\end{array}$ \\
\hline M31 & $30 \times 30$ & 5.88 & Semi-rigid \\
M32 & $40 \times 40$ & 8.68 & Semi-rigid \\
M21 & $50 \times 50$ & 12.27 & Semi-rigid \\
M33 & $60 \times 60$ & 16.41 & Semi-rigid \\
\hline
\end{tabular}

Figure 12. Effect of gusset plate dimensions (with one gusset plate).

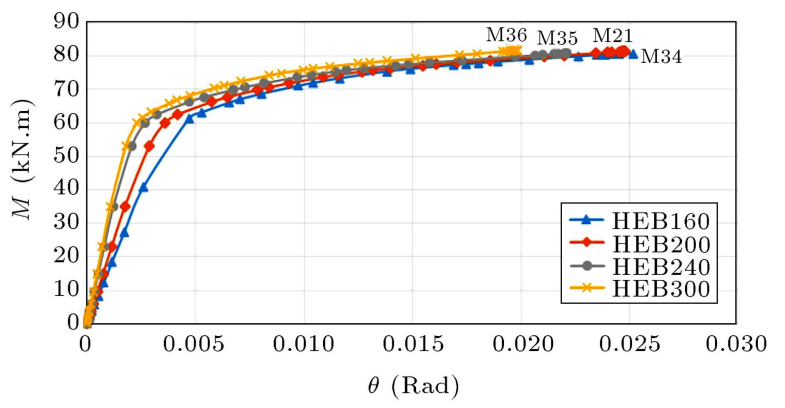

\begin{tabular}{llcc}
\hline Model & $\begin{array}{c}\text { Column } \\
\text { section }\end{array}$ & $\begin{array}{c}\text { Dimensionless } \\
\text { parameter, } \\
\frac{K_{s} L}{E I}\end{array}$ & $\begin{array}{c}\text { Connection } \\
\text { classification }\end{array}$ \\
\hline M34 & HEB160 & 9.76 & Semi-rigid \\
M21 & HEB200 & 12.27 & Semi-rigid \\
M35 & HEB240 & 17.46 & Semi-rigid \\
M36 & HEB300 & 20.49 & Rigid \\
\hline
\end{tabular}

Figure 13. Effect of column section (with one gusset plate).

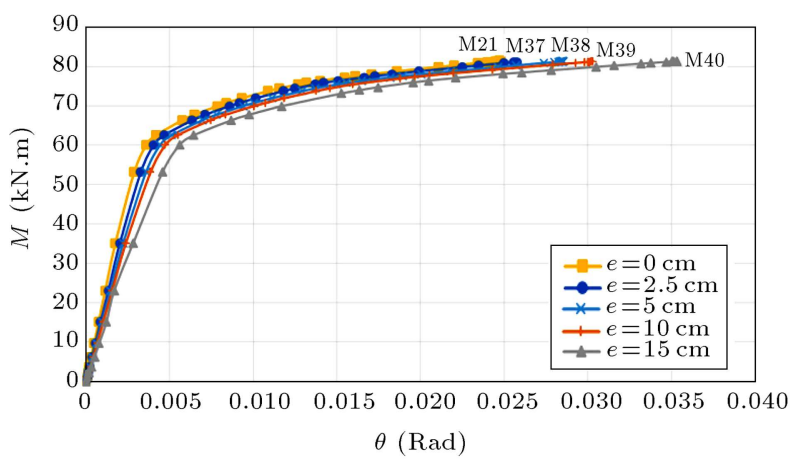

\begin{tabular}{cccc}
\hline Model & $\begin{array}{c}\text { Clip distance } \\
\text { at the end of } \\
\text { gusset plate, } e \\
(\mathbf{c m})\end{array}$ & $\begin{array}{c}\text { Dimensionless } \\
\text { parameter, } \\
\frac{K_{s} L}{E I}\end{array}$ & $\begin{array}{c}\text { Connection } \\
\text { classification }\end{array}$ \\
\hline M21 & 0 & 12.27 & Semi-rigid \\
M37 & 2.5 & 10.58 & Semi-rigid \\
M38 & 5 & 9.67 & Semi-rigid \\
M39 & 10 & 8.93 & Semi-rigid \\
M40 & 15 & 7.48 & Semi-rigid \\
\hline
\end{tabular}

Figure 14. Effect of clip distance at the end of gusset plate (with one gusset plate).

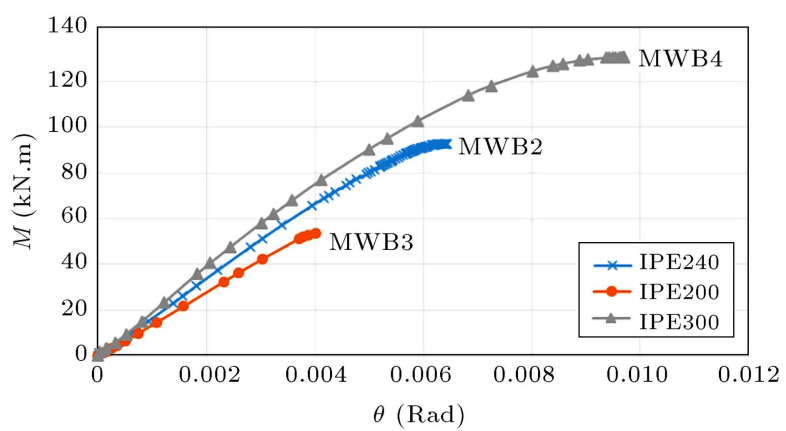

\begin{tabular}{llcc}
\hline Model & $\begin{array}{c}\text { Beam } \\
\text { section }\end{array}$ & $\begin{array}{c}\text { Dimensionless } \\
\text { parameter, } \\
\frac{K_{s} L}{E I}\end{array}$ & $\begin{array}{c}\text { Connection } \\
\text { classification }\end{array}$ \\
\hline MWB2 & IPE240 & 9.79 & Semi-rigid \\
MWB3 & IPE200 & 17.43 & Semi-rigid \\
MWB4 & IPE300 & 5.55 & Semi-rigid \\
\hline
\end{tabular}

Figure 15. Effect of beam section on bolted connections (with two gusset plates).

nection decrease, while ultimate rotation of connection increases. Moreover, connection transforms from rigid to semi-rigid.

The results for models "MWB2" to "MWB13" are shown in Figures 15 to 18 and the results of model "MWB1" regarding monotonic loading and cyclic loading are shown in Figures 19 and 20, respectively.

Comparison of bolted models with welded models indicates that the bolted connections have lower initial stiffness, ultimate moment, and rigidity, but higher ultimate rotation in the same conditions. 


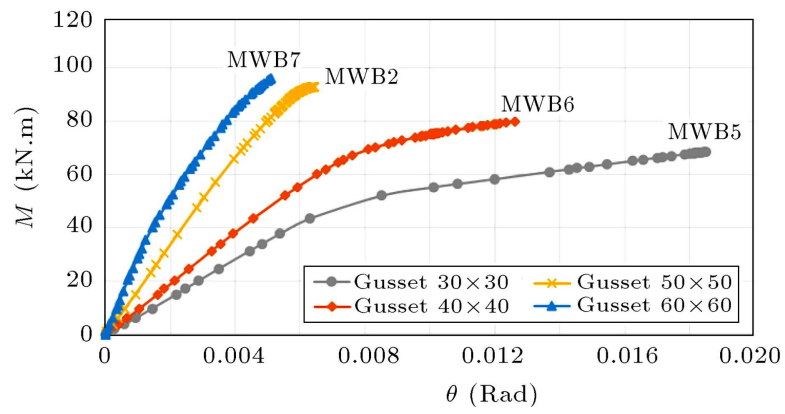

\begin{tabular}{cccc}
\hline Model & $\begin{array}{c}\text { Gusset plate } \\
\text { dimensions } \\
(\mathbf{c m})\end{array}$ & $\begin{array}{c}\text { Dimensionless } \\
\text { parameter } \\
\frac{K_{s} L}{E I}\end{array}$ & $\begin{array}{c}\text { Connection } \\
\text { classification }\end{array}$ \\
\hline MWB2 & $50 \times 50$ & 9.79 & Semi-rigid \\
MWB5 & $30 \times 30$ & 4.1 & Semi-rigid \\
MWB6 & $40 \times 40$ & 5.73 & Semi-rigid \\
MWB7 & $60 \times 60$ & 17.36 & Semi-rigid \\
\hline
\end{tabular}

Figure 16. Effect of gusset plate dimensions on bolted connections (with two gusset plates).

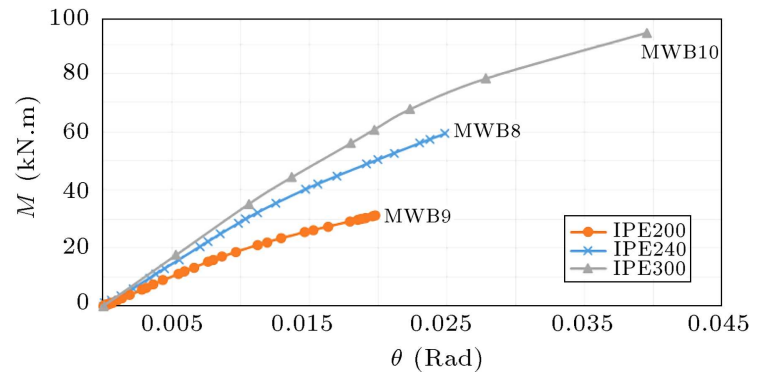

\begin{tabular}{cccc}
\hline Model & $\begin{array}{c}\text { Beam } \\
\text { section }\end{array}$ & $\begin{array}{c}\text { Dimensionless } \\
\text { parameter, } \\
\frac{K_{s} L}{E I}\end{array}$ & $\begin{array}{c}\text { Connection } \\
\text { classification }\end{array}$ \\
\hline MWB8 & IPE240 & 2.14 & Semi-rigid \\
MWB9 & IPE200 & 2.95 & Semi-rigid \\
MWB10 & IPE300 & 1.13 & Simple \\
\hline
\end{tabular}

Figure 17. Effect of beam section on bolted connections (with one gusset plate).

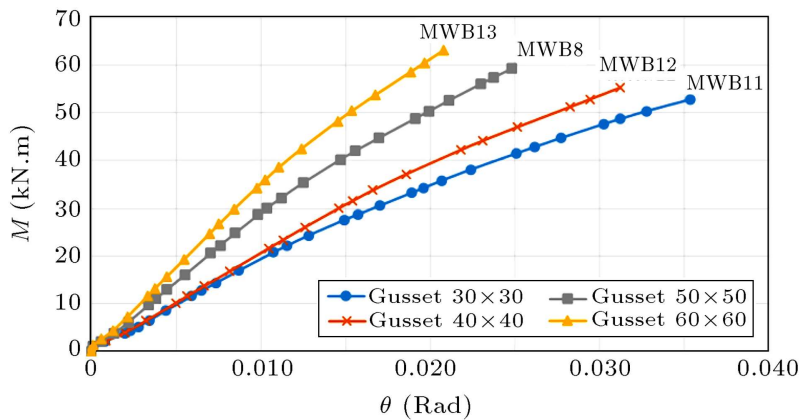

\begin{tabular}{cccc}
\hline Model & $\begin{array}{c}\text { Gusset plate } \\
\text { dimensions } \\
(\mathbf{c m})\end{array}$ & $\begin{array}{c}\text { Dimensionless } \\
\text { parameter, } \\
\frac{K_{s} L}{E I}\end{array}$ & $\begin{array}{c}\text { Connection } \\
\text { classification }\end{array}$ \\
\hline MWB8 & $50 \times 50$ & 2.14 & Semi-rigid \\
MWB11 & $30 \times 30$ & 1.52 & Simple \\
MWB12 & $40 \times 40$ & 1.66 & Simple \\
MWB13 & $60 \times 60$ & 2.95 & Semi-rigid \\
\hline
\end{tabular}

Figure 18. Effect of gusset plate dimensions on bolted connections (with one gusset plate).

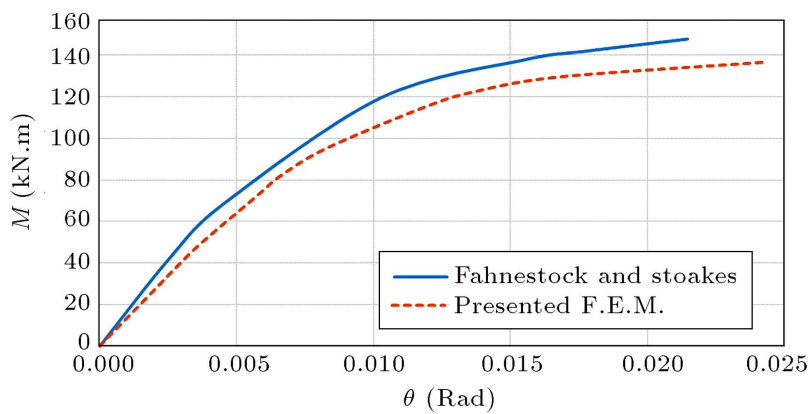

Figure 19. Moment-rotation curve of model "MWB1".

In Figure 19, moment-rotation curve of the model "MWB1" is illustrated for two cases; the first one is the presented FEM model and the other one is the Fahnestock and Stoakes [24] model.

\subsection{Finite element model results with cyclic loading}

The models "M1," "M21," and "MWB1" are analyzed

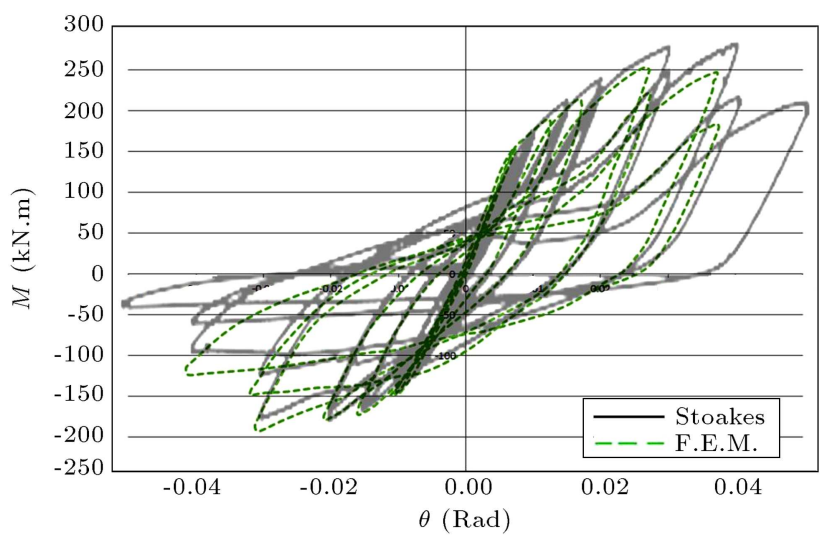

Figure 20. Moment-rotation curve of model "MWB1" vs. experimental results.

according to the cyclic loading with SAC loading protocol [17]. The "MWB1" results are confirmed by the experimental test that has been conducted by Stoakes [14] as it is shown in Figure 20. The results of 
"M1" and "M21" models are shown in Figures 21 and 22 , respectively.

As shown in Figure 20, the outcome of FEM is in a good conformity with experimental results. Moreover, as shown in Figures 21 and 22, the monotonic loading moment-rotation curve is approximately placed on push of cyclic loading moment-rotation curve.

\subsection{Comparison of FEM results with analytical model results}

The initial stiffness and ultimate moment of connections in models "M1" to "M40", FEM models, and analytical models are compared with each other in Table 4. Evidently, the average percentage of error and absolute average percentage of error in the

Table 4. Comparison of initial stiffness and ultimate moment for FEM models and analytical models.

\begin{tabular}{|c|c|c|c|c|c|c|c|}
\hline Model & $\begin{array}{c}\text { The percentage } \\
\text { of error in } \\
\text { calculating the } \\
\text { ultimate moment }\end{array}$ & $\begin{array}{l}\text { The percentage } \\
\text { of error in } \\
\text { calculating the } \\
\text { initial stiffness }\end{array}$ & $\begin{array}{c}M_{u} \\
\text { (analytical) } \\
(\text { KN.m) }\end{array}$ & $\begin{array}{c}M_{u} \\
(\text { FEM) } \\
\text { (KN.m) }\end{array}$ & $\begin{array}{c}K_{i} \\
(\text { analytical }) \\
\left(\text { KN.m } \times 10^{4}\right)\end{array}$ & $\begin{array}{c}\boldsymbol{K}_{\boldsymbol{i}} \\
(\mathrm{FEM}) \\
\left(\mathrm{KN} . \mathbf{m} \times \mathbf{1 0}^{\mathbf{4}}\right)\end{array}$ & $\begin{array}{c}\boldsymbol{K}_{p} / \boldsymbol{K}_{i} \\
(\%)\end{array}$ \\
\hline M1 & -4.1 & 2.6 & 88 & 91.6 & 6.99 & 6.81 & 20 \\
\hline M2 & -6.1 & 1.4 & 68.5 & 72.7 & 6.62 & 6.53 & 20 \\
\hline M3 & -7 & 7.4 & 53 & 56.7 & 6.21 & 5.75 & 20 \\
\hline M4 & -3 & 6.9 & 116 & 119.5 & 7.55 & 7.03 & 18 \\
\hline M5 & 2.8 & -14.9 & 151 & 146.8 & 8.06 & 9.26 & 15 \\
\hline M6 & -5.4 & -6.7 & 262.6 & 276.7 & 9.57 & 10.21 & 7 \\
\hline M7 & -2.5 & -15.9 & 88 & 90.2 & 4.98 & 5.77 & 20 \\
\hline M8 & -3.5 & -1.8 & 88 & 91.1 & 6.04 & 6.15 & 20 \\
\hline M9 & -4.4 & 3.8 & 88 & 91.9 & 7.41 & 7.13 & 20 \\
\hline M10 & -4.8 & 12.8 & 88 & 92.2 & 8.39 & 7.32 & 20 \\
\hline M11 & 11.6 & 11.7 & 88 & 77.8 & 3.26 & 2.88 & 10 \\
\hline M12 & 5.9 & 12.9 & 88 & 82.8 & 4.95 & 4.31 & 15 \\
\hline M13 & -14.4 & -18.4 & 88 & 100.7 & 9.38 & 11.11 & 20 \\
\hline M14 & -4.1 & -14.8 & 88 & 91.6 & 5.06 & 5.81 & 20 \\
\hline M15 & -4.2 & -10.5 & 88 & 91.7 & 9.16 & 10.12 & 20 \\
\hline M16 & -4.1 & -14.3 & 88 & 91.6 & 12.63 & 14.44 & 20 \\
\hline M17 & -4.2 & 5.5 & 88 & 91.7 & 6.33 & 5.98 & 15 \\
\hline M18 & -4.1 & 12.8 & 88 & 91.6 & 5.69 & 4.96 & 15 \\
\hline M19 & -4 & 5.8 & 88 & 91.5 & 4.5 & 4.24 & 15 \\
\hline M20 & -4 & -16.8 & 88 & 91.5 & 3.46 & 4.04 & 15 \\
\hline M21 & -1.2 & 1.80 & 80 & 81.4 & 2.05 & 2.01 & 5 \\
\hline M22 & -3.4 & -0.78 & 68 & 70.7 & 1.95 & 1.97 & 7 \\
\hline M23 & -14.3 & -3.04 & 53 & 60.6 & 1.85 & 1.91 & 20 \\
\hline M24 & -1.5 & 5.60 & 93 & 94.8 & 2.18 & 2.06 & 5 \\
\hline M25 & 5.1 & 6.53 & 119 & 113 & 2.31 & 2.16 & 5 \\
\hline M26 & 14.0 & 11.64 & 184 & 158.4 & 2.68 & 2.37 & 5 \\
\hline M27 & -22.7 & -15.22 & 62 & 76.5 & 1.47 & 1.69 & 5 \\
\hline M28 & -11.8 & -0.74 & 71 & 79.8 & 1.78 & 1.79 & 5 \\
\hline M29 & 7.2 & 9.87 & 88 & 81.7 & 2.30 & 2.07 & 5 \\
\hline M30 & 6.9 & 19.52 & 88 & 82 & 2.65 & 2.13 & 5 \\
\hline M31 & 27.1 & -10.52 & 66 & 47.8 & 0.87 & 0.96 & 5 \\
\hline M32 & -7.2 & -0.57 & 59 & 63.6 & 1.41 & 1.42 & 5 \\
\hline M33 & -8.9 & 2.08 & 88 & 95.9 & 2.75 & 2.69 & 5 \\
\hline M34 & -0.4 & -12.93 & 80 & 80.7 & 1.42 & 1.6 & 5 \\
\hline M35 & -1.4 & -1.90 & 80 & 81.5 & 2.81 & 2.86 & 5 \\
\hline M36 & -1.6 & 19.17 & 80 & 81.7 & 4.16 & 3.36 & 5 \\
\hline M37 & -1.2 & 10.68 & 80 & 81.4 & 1.94 & 1.73 & 5 \\
\hline M38 & -1.1 & 12.89 & 80 & 81.3 & 1.84 & 1.6 & 5 \\
\hline M39 & -1.0 & 12.93 & 80 & 81.2 & 1.68 & 1.46 & 5 \\
\hline M40 & -0.7 & 19.44 & 80 & 81 & 1.53 & 1.23 & 5 \\
\hline
\end{tabular}




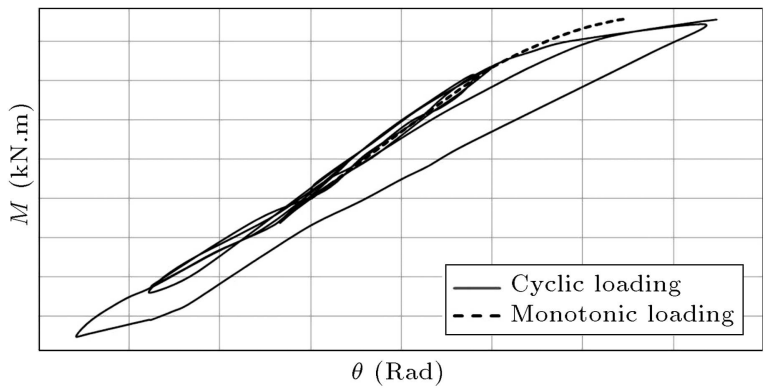

Figure 21. Moment-rotation curve of model "M1" for monotonic and cyclic loading.

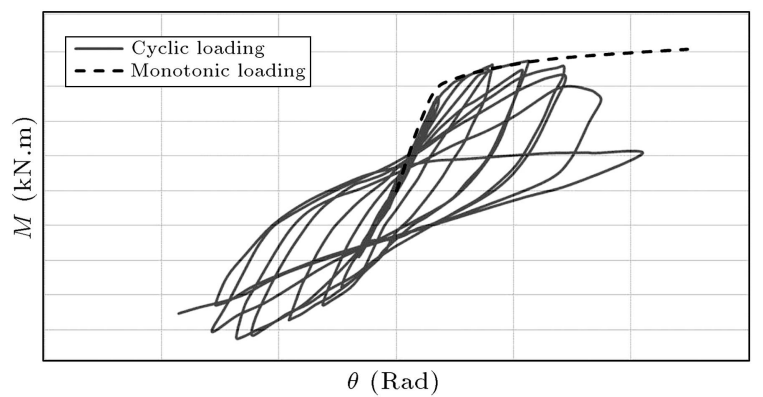

Figure 22. Moment-rotation curve of model "M21" for monotonic and cyclic loading.

calculation of initial stiffness are equal to $1.40 \%$ and $9.39 \%$, respectively. Moreover, the average percentage of error and absolute average percentage of error in the calculation of ultimate moment are equal to $-2.04 \%$ and $6.07 \%$, respectively. Apparently, as it is observed in the comparison of models and two methods, it is discerned that the average error between the two methods is less than $10 \%$ for both initial stiffness and ultimate moment, and the errors are in the acceptable range.

\section{Conclusion}

According to the results in the previous sections, the following consequences can be discerned:

- By adding gusset plate to double-web angle connection, the connection does not have a hinge (simple) behavior and performs as a semi-rigid or rigid connection. Predominantly, in fully welded connections, the rigidity of connection is higher than that of bolted connections;

- The most essential parameters regarding the connection are beam depth, gusset plate dimensions, and existence of gusset plate on both or one side of the beam;

- Increasing beam depth will increase the initial stiffness, ultimate moment, and ultimate rotation of connection; nonetheless, it reduces the rigidity of connection;

- Increasing gusset plate dimensions will increase rigidity, initial stiffness, and ultimate moment of connection; nonetheless, it reduces ultimate rotation of the connection;

- Removing the gusset plate from one side of the beam along with reducing the number of gusset plates around the beam will significantly reduce the initial stiffness, ultimate moment, and rigidity of connection; nonetheless, it increases ultimate rotation of the connection.

\section{Nomenclature}

G

$F_{y}$

$F_{u}$

$d_{\text {beam }}$

$Z_{b} \quad$ Plastic section modulus of beam

$L_{a} \quad$ Web angle length

$t \quad$ Web angle thickness

$A_{b} \quad$ Area of bolt

$L_{g v} \quad$ Vertical length of gusset plate (in case of clipping the end of gusset plate), this parameter shall be considered as vertical length of welded gusset plate, as shown in Figure 2

$L_{g h} \quad$ Horizontal length of gusset plate (in case of clipping the end of gusset plate), this parameter shall be considered as horizontal length of welded gusset plate, as shown in Figure 2

$e \quad$ The clipping distance at the end of gusset plate, as shown in Figure 2

$t_{g} \quad$ Gusset plate thickness

$b_{f c} \quad$ Column flange width

$t_{f c} \quad$ Column flange thickness

$h_{w c} \quad$ Column web height

$t_{w c} \quad$ Column web thickness

\section{References}

1. Nader, M.N. and Astaneh-Asl, A. "Dynamic behavior of flexible, semi-rigid and rigid steel frames", Journal of Constructional Steel Research, 18, pp. 179-92 (1991).

2. Wilson, W. and Moore, H., Tests to Determine the Rigidity of Riveted Joints of Steel Structures, IllinoisUrbana: University of Illinois bulletin (1917).

3. Rathbun, J.C. "Elastic properties of riveted connections", Transactions of ASCE, 101, pp. 524-563 (1936). 
4. McMullin, K.M. and Astaneh, A. "Analytical and experimental studies of double-angle framing connections", Report no. UCB/SEMM-88/14, Department of Civil Engineering, University of California, Berkeley, California (1988).

5. Abolmaali, A., Kukreti, A. and Razavi, H. "Hysteresis behavior of semi-rigid double web angle steel connections", Journal of Constructional Steel Research, 59(8), pp. 1057-1082 (2003).

6. Astaneh-Asl, A., Goel, S.C. and Hanson, R.D. "Behavior of steel diagonal bracing", Proceedings, ASCE Conference, St Luis, pp. 81-522 (1981).

7. Astaneh-Asl, A., Goel, S.C. and Hanson, R.D. "Cyclic behavior of double angle bracing members with end gusset plates", Report no. UMEE 82R7, University of Michigan, Ann Arbor (1982).

8. Astaneh-Asl, A., Goel, S.C. and Hanson, R.D. "Cyclic behavior of double angle bracing members with bolted connections", Proceedings, Eighth World Conference on Earthquake Engineering, VI, San Francisco, pp. 249-256 (1984).

9. Astaneh-Asl, A. and Goel, S.C. "Cyclic in-plane buckling of double angle bracing", Journal of Structural Engineering. ASCE, 110(9), pp. 2036-2055 (1984).

10. Astaneh-Asl, A., Goel, S.C. and Hanson, R.D. "Cyclic out-of-plane buckling of double angle bracing", Journal of Structural Engineering, ASCE, 111(5), pp. 11351153 (1985).

11. Astaneh-Asl, A. "Seismic behaviour and design of gusset plates", Steel Tips, Structural Steel Education Council, Moraga, CA (1998).

12. Lehman, D.E., Roeder, C.W., Herman, D., Johnson, S. and Kotulka, B. "Improved seismic performance of gusset plate connections", Journal of Structural Engineering, ASCE, 134(6), pp. 890-901 (2008).

13. Gross, J.L. and Cheok, G. "Experimental study of gusseted connections for laterally braced steel buildings", National Institute of Standards and Technology Report, NISTIR 89-3849 (1988).

14. Stoakes, C.D. "Beam-column connection flexural behavior and seismic collapse performance of concentrically braced frames", PHD thesis, University of Illinois at Urbana-Champaign. (2012).

15. Mohamadi-shooreh, M. and Mofid, M. "Prediction of the yielding moment of flush endplate splice connections using finite element modeling", Scientia Iranica, 20(2), pp. 270-277 (2013).

16. AWS Committee on Structural Welding, Structural Welding Code-Steel, Miami, Florida, American Welding Society (2000).

17. SAC Joint Venture "Protocol for fabrication, inspection, testing, and documentation of beam-column connection tests and other experimental specimens", SAC
Joint Venture, Report No. SAC/BD-97/02, Sacramento, California (1997).

18. Nascimbene, R. "Towards non-standard numerical modeling of thin-shell structures: Geometrically linear formulation", International Journal of Computational Methods in Engineering Science and Mechanics, 15(2), pp. 126-141 (2014).

19. Silva, L.S., Santiago, A. and Real, P.V. "Post-limit stiffness and ductility of end-plate beam-to-column steel joints", Computers and Structures, 80(5-6), pp. 515-531 (2002).

20. AISC, Specification for Structural Steel Building, ANSI/AISC 360-10, Chicago (IL): American Institute of Steel Construction (2010).

21. Mohamadi-Shoore, M. and Mofid, M. "New modeling for moment-rotation behavior of bolted endplate connections", Scientia Iranica, 18(4), pp. 827-834 (2011).

22. Lee, S.-S. and Moon, T.-S. "Moment-rotation model of semi-rigid connections with angles", Engineering Structures, 24(2), pp. 227-237 (2002).

23. Stelmack, T., Marley, M. and Gerstle, K. "Analysis and tests of flexibly connected steel frames", Journal of Structural Engineering, 112(7), pp. 1573-1588 (1986).

24. Fahnestock, L.A. and Stoakes, C.D. "Cyclic Behavior and Performance of Beam-Column Connections in Concentrically Braced Frames. Don't mess With structural engineers 2009: Expanding our role"; Proceedings of 2009 Structures Congress, Austin, Texas, pp. 1-8 (2009).

\section{Biographies}

Massood Mofid is Professor of Civil and Structural Engineering at Sharif University of Technology. He received his BS degree from University of Tehran, his MS and PhD degrees from Rice University, Houston, Texas. His research applies the principles of structural dynamics and engineering mechanics.

Amir Reza Tabkhi Wayghan received the BSc and MSc degrees in Civil Engineering from Sharif University of Technology, Tehran, Iran, in 2011 and 2013, respectively. He has continued his studies as a $\mathrm{PhD}$ candidate in Structural Engineering at the same university since 2013. He is interested in the fields of steel connections and their behavior, application of Fiber Reinforced Polymer (FRP), industrial buildings, and finite element method in static and dynamic problems. 